Abstracta Iranica Abstracta Iranica

Revue bibliographique pour le domaine irano-aryen

Volume 29 | 2008

Comptes rendus des publications de 2006

\title{
Networks in transition - wartime migration in Afghanistan. Oslo, Unipub, 2006, 384 p.
}

\section{Anicée Van Engeland}

\section{(2) OpenEdition}

1 Journals

\section{Édition électronique}

URL : http://journals.openedition.org/abstractairanica/32872

DOI : 10.4000/abstractairanica.32872

ISSN : 1961-960X

Éditeur :

CNRS (UMR 7528 Mondes iraniens et indiens), Éditions de l'IFRI

\section{Édition imprimée}

Date de publication : 15 mai 2008

ISSN : 0240-8910

\section{Référence électronique}

Anicée Van Engeland, « Networks in transition - wartime migration in Afghanistan. Oslo, Unipub, 2006, 384 p. », Abstracta Iranica [En ligne], Volume 29 | 2008, document 395, mis en ligne le 15 septembre 2008, consulté le 26 septembre 2020. URL : http://journals.openedition.org/abstractairanica/32872 ; DOI : https://doi.org/10.4000/abstractairanica.32872

Ce document a été généré automatiquement le 26 septembre 2020.

Tous droits réservés 


\title{
Networks in transition - wartime migration in Afghanistan. Oslo, Unipub, 2006, 384 p.
}

\author{
Anicée Van Engeland
}

Cet ouvrage analyse les mouvements migratoires afghans provoqués par les guerres successives qui ont frappé le pays. Au cœur de ce travail, l'A. cherche à comprendre comment les réseaux des individus sont transformés par la guerre et l'exil. Il analyse ainsi la migration dans la guerre, les liens sociaux que les réfugiés et les déplacés tissent entre eux. Cette étude menée en Iran auprès des réfugiés afghans est l'illustration de la capacité des individus à mobiliser des ressources, à prendre des décisions et à se gérer même lorsqu'ils vivent un stress intense.

\section{INDEX}

Thèmes : 13.2. Afghanistan

\section{AUTEURS}

ANICÉE VAN ENGELAND

European University Institute - Florence 